\title{
Structural breaks in finance growth nexus: the study of Indonesia
}

\author{
*Bidisha Mukhopadhyay ${ }^{1}$ and Rudra P. Pradhan ${ }^{2}$ \\ Vinod Gupta School of Management, Indian Institute of Technology Kharagpur India \\ * dishaecon@gmail.com
}

\begin{abstract}
This paper empirically investigates the finance-growth nexus for an annual data set of Indonesia during the last two decades. The purpose is to examine the causal relationship between financial development and economic growth in Indonesia and also to test the structural breaks in the finance-growth relationship to investigate the change in policy regimes. To examine the causal relationship between financial development and economic growth, the newly proposed ARDL bound testing approach by Pesaran et al. (1996) has been applied .The estimated results support the view of Lucas (1988) that finance doesn't matter for economic growth. Structural break is identified in the year 1997 in Indonesia with the estimated finance-growth relationship. The stability of the estimated relationship is examined with break-point Chow tests ( $\mathrm{F}$ tests).
\end{abstract}

Keywords: Financial development, economic growth, structural break

\section{Introduction}

The relationship between financial development and economic growth has been a subject of great interest and debate among economists for many years. In the literature the term 'financial development' is defined as the improvement in quantity, quality and efficiency of financial intermediary services. Financial intermediary means institution that helps channeling funds between lenders to borrowers. In a broader sense financial development signifies development of the overall financial sector. The existing literature points out that a well-functioning economy needs a sound financial system for the efficient mobilization of resources and openness is the key determinant of cross-country differences in the development of financial systems. As far back as 1873, the link between financial development and growth was first demonstrated in the literature by Bagehot (1873) and Hicks (1969), who pointed out that industrialization of England, was possible because of the use of the financial system to mobilize productive financial capital (Liang \& Teng, 2006). McKinnon (1973) and Shaw (1973) brought the issue of financial development in the process of economic growth at the center of research (Christopoulos \& Tsionas, 2004). Empirical studies in the finance-growth relationship are voluminous, but there is still absence of a consensus of opinion (Antonios, 2010). One possible reason for these varying positions may be that different countries are in different economic and financial conditions. That is, the relationship between financial development and economic growth may not be linear. There are few studies regarding the presence of non-linearity or structural breaks in the finance-growth relationship.

Considering the gap areas in the existing literature this study represents an attempt to provide new evidence on the causal relationship between financial development and economic growth in the context of Indonesia over the last two decades. Indonesia continues to consolidate its robust economic performance, but capital flows and financial markets were especially volatile there, and policy makers appear to have managed this to a large extent. Hence, in the context of Indonesia longer-term structural issues need to be addressed to ensure that economic growth can improve and leads to sustainable improvements in Indonesians' quality of life. In this paper ARDL bound testing approach by Pesaran et al. (1999) has been applied to examine the causal relationship between financial development and economic growth in Indonesia. To test for structural breaks in the finance-growth nexus, the stability of the estimated relationship is examined with break-point Chow tests (F-tests). The rest of the paper is organized as follows: Section II analyses the background literature, Section III describes the rationality of the study. Section IV discusses the model, database, and econometric methodology. Section V presents the empirical results and its discussion thereof. Section VI presents conclusion with policy implications. 


\section{Background Literature}

According to Bagehot (1873), Schumpeter (1934), Hicks (1969), McKinnon (1973), Shaw (1973), Christopoulos \& Tsionas (2004) and some others financial development acts as an engine of economic growth (Ketteni, 2007). This Supply-leading' hypothesis shows finance as a contributing factor in economic growth. The view is that, financial sector transfers resources from the low-growth sector to modern high-growth sectors, and promotes and stimulates entrepreneurial responses in these modern sectors (Christopoulos \& Tsionas, 2004). 'Supply leading' has two functions: To transfer resources from the traditional, low-growth sectors to the modern high-growth sectors and to promote and stimulate an entrepreneurial response in these modern sectors. The "McKinnon-Shaw" hypothesis contends that financial liberalization in the form of an appropriate rate of return on real cash balances is a vehicle of promoting economic growth. The view is that a well functioning financial system would induce technological innovation by identifying, selecting, and funding those entrepreneurs who would be expected to successfully implement their products and productive processes. The structuralists contend that the quantity and composition of financial variables induces economic growth by directly increasing saving in the form of financial assets, thereby, encouraging capital formation and hence, economic growth.

Various studies like Levine (1997) and Kemal et al., (2007) have shown that financial development sometimes may be harmful to growth. Although financial institutions facilitate risk amelioration and the efficient allocation of resources, it may dampen growth by lowering risk as well as return (Kemal et al., 2007). The theories examine the volatility spillover between the stock market and the foreign exchange market. The results from the volatility modelling show that the behaviour of both the stock exchange and the foreign exchange markets are interlinked. The returns of one market are affected by the volatility of other market. Robinson (1952), Liang \& Teng (2006), Odhiambo (2008), and some others in their 'Demand-following' hypotheses have viewed finance as dependent upon economic growth. Robinson (1952) claims that "where enterprise leads, finance follows"-it is the economic development which creates the demand for financial services and not vice versa. Financial development follows economic growth as a result of increased demand for financial services.

The study of Odhiambo (2008) examines the direction of causality between financial development and economic growth in Kenya using a dynamic Granger causality model. The study has been motivated by the current debate on the inter-temporal causal relationship between financial development and economic growth in developing countries. The thrust of this debate has been whether there exists a finance-led growth response or a growth-led finance response between the two variables. To this end the study uses three proxies of financial development against real GDP per capita (a proxy for economic growth). The empirical results reveal that, although the causality between financial development and economic growth in Kenya is sensitive to the choice of measure for financial development, on balance the demand following response tends to predominate. The study, therefore, concludes that the argument that financial development unambiguously leads to economic growth can only be taken with a pinch of salt. Finance is regarded as a relatively unimportant factor in growth according to this view (Robinson, 1952; Lucas, 1988). According to Lucas (1988) the role of financial development in economic growth has been overstressed. This paper studies whether there is any causal link between financial development indicators and economic growth, using Sims-Geweke causality tests performed in the large panel data set provided by Levine, Loayza and Beck (2000). In sharp contrast to their findings, no evidence was found of any positive unidirectional causal link from financial development indicators to economic growth. Furthermore, there are some studies (Calderon \& Liu, 2003, Yucel, 2009) focusing on the bidirectional nature of causality between financial development and economic growth.

Despite the wealth of research in the finance-growth area, no one theory has gained the full support of the entire economic community; on the contrary, somewhat conflicting and often contradictory findings have left many deeply puzzled. One possible reason for these varying positions may be that different countries are in different economic and financial conditions. That is, the relationship between financial development and economic growth may not be linear, but rather simply be dependent on the conditions. Keeping this in mind, one question arises: precisely which conditions must be altered as an important policy issue so that the country can enjoy the positive finance-growth nexus? The study by Rioja and Valev (2004), using the data for 74 countries, have shown that conditions are significant factor behind the finance-growth nexus. Shen and Lee (2006) re-studied the relationship between financial development and real GDP per capita growth in 48 countries with conditional variables (financial liberalization, two sets of country development dummies, crises in banking and currency dummies, the creditor protection 
index as well as the anti-director and corruption indices) and found that the relationship between growth and bank development is better described as a weak inverse U-shape. Their results have shown that the conditional variables of financial liberalization, high-income level, and good shareholder protection mitigate the negative impacts of banking development on growth.

There are few studies regarding the presence of structural breaks in the finance-growth relationship. The study by Levine (1997) has shown the presence of structural breaks in the finance-growth relationship. The study of Chia-Hsin Hu (2002) has investigated the presence of structural breaks due to policy changes in the linkage between banking sector development and economic growth of Taiwan economy. Rioja and Valev (2004) have analyzed the occurrence of structural breaks in the finance-growth relationship of a panel of 74 countries. The study by Liang and Teng, (2007) investigated empirically the causality between financial development and economic growth for 11 sample countries in a structural break framework via minimum Lagrange multiplier unit-root test and Hsiao's causality test. They found most of the series can be more accurately characterized as a segmented trend stationary process around structural breaks as opposed to a stochastic unit-root process. Besides, they found different causality patterns in different sample countries. In his one of the recent study Jacques Loesse ESSO (2010) has used the Hansen (1992) and Hansen and Seo (2002) approach to cointegration with structural change and the procedure for non-causality test of Toda and Yamamoto (1995). The study tested for the instability of the long-run relationship between finance and growth and tested for cointegration in presence of breakpoint. The study has shown that there is a long-run relationship with structural break between financial development and economic growth in six countries, namely, Burkina Faso, Cape Verde, Cote d'Ivoire, Ghana, Liberia, and Sierra Leone.

\section{Rationality of the Study}

The Economy of Indonesia is the largest economy in Southeast Asia, is one of the emerging market economies of the world, and also the member of G-20 major economies. In the mid-1980s, the government of Indonesia began eliminating regulatory obstacles to economic activity. The steps were aimed primarily at the trade and finance sectors and were designed to stimulate employment and growth in the non-oil export sector. Annual real GDP growth averaged nearly 7\% from 1987-1997 and most analysts recognized Indonesia as a newly industrialized economy and emerging market. High levels of economic growth from 1987-1997 masked a number of structural weaknesses in Indonesia's economy. The policy makers appear to have managed the financial turmoil to a large extent. Hence, it is necessary in the context of Indonesia to address longer-term structural issues and to find out the causal relationship between financial development and economic growth.

\section{The Model, Database, and Methodology}

In this study, the short- and long run dynamic relationships between economic growth and financial depth are estimated for Indonesia using the newly proposed ARDL bound testing approach which was initially introduced by Pesaran et al. (1996). The ARDL has numerous advantages. Firstly, unlike the most widely method used for testing cointegration, the ARDL approach can be applied regardless of the stationary properties of the variables in the sample, and it allows for inferences on long-run estimates which is not possible under the alternative cointegration procedures. In other words, this procedure can be applied irrespective of whether the series are I (0), I (1), or fractionally integrated (Pesaran and Smith, 1999), thereby avoiding problems resulting from non-stationary time series data .Secondly, the ARDL model takes a sufficient number of lags to capture the data generating process in a general-to-specific modeling framework. It estimates $(\mathrm{p}+1) \mathrm{k}$ number of regressions in order to obtain an optimal lag length for each variable, where $\mathrm{p}$ is the maximum lag to be used, $\mathrm{k}$ is the number of variables in the equation. Finally, the ARDL approach provides robust results for a smaller sample size of cointegration analysis. The ARDL model used in this study can be written as follows:

$\mathrm{GDP}_{\mathrm{t}}=\alpha_{0}+\alpha_{1} \mathrm{FD}_{\mathrm{t}}+\alpha_{2} \mathrm{SI}_{\mathrm{t}}+\alpha_{3} \mathrm{INF}_{\mathrm{t}}+\mathrm{E}_{\mathrm{t}}$

Where, $\mathrm{GDP}_{\mathrm{t}}=$ real output at time $t, \mathrm{FD}_{\mathrm{t}}=$ a measure of financial depth, $\mathrm{SI}_{\mathrm{t}}=$ the share of investment, $\mathrm{INF}_{\mathrm{t}}$ $=$ inflation, and $E_{t}=$ an error term. Economic Control Variables are: the log of per capita GDP in terms of PPP, the inflation rt. \& the share of investment (SI) is the share of gross fixed capital formation to nominal GDP. The empirical analysis is based on annual time-series data on real GDP per capita, FD Indicators and other control variables of Indonesia over the period 1990-2009. Data are obtained from the International Financial Statistics Year Book (various issues) published by the International Monetary Fund. 


\section{Vector Error Correction Model (VECM) Framework}

To examine the multivariate causality relationship among the variables, the study employs the vector error correction model (VECM) framework. The VECM regresses the changes in both the dependent and independent variables on lagged deviations. Following the study of Chang (2001), the multivariate causality test is therefore formulated as follows:

$\Delta \mathrm{Z}_{\mathrm{t}}=\delta+\Gamma_{\mathrm{i}} \Delta \mathrm{Z}_{\mathrm{t}-1}+\ldots+\Gamma_{\mathrm{k}} \Delta \mathrm{Z}_{\mathrm{t}-\mathrm{k}}+\prod_{\mathrm{i}} \Delta \mathrm{Z}_{\mathrm{t}-\mathrm{k}}+\mathrm{U}_{\mathrm{t}}$

Where $\mathrm{Z}_{\mathrm{t}}$ is an $\mathrm{n} \times 1$ vector of variables and $\delta$ is an $\mathrm{n} \times 1$ vector of constant, respectively. In our case, $\mathrm{Z}_{\mathrm{t}}=$ (GDP, FD, SI, INF). $\Gamma$ is an $\mathrm{n} \times \mathrm{n}$ matrix (coefficients of the short-run dynamics), $\Pi=\alpha \beta$ ' where $\alpha$ is an $\mathrm{nx} 1$ column vector (the matrix of loadings) representing the speed of short-run adjustment to disequilibrium, and $\beta$ ' is an $1 \mathrm{x} \mathrm{n}$ cointegrating row vector (the matrix of cointegrating vectors) which indicates the matrix of long-run coefficients such that $Y_{t}$ converges in their long-run equilibrium. Finally, $U_{t}$ is an $n \times 1$ vector of white noise error term, and $\mathrm{k}$ is the order of auto regression. A test statistic is calculated by taking the sum of the squared F-statistics of $\Gamma$ and t-statistics of $\Pi$. The multivariate causality test is implemented by calculating the F-statistics (Wald-test) based on the null-hypothesis that the set of coefficients $(\Gamma)$ on the lagged values of independent variables are not statistically different from zero. If the null-hypothesis is not rejected, then it can be concluded that the independent variables do not cause the dependent variable. To test for structural breaks in the finance-growth nexus, the stability of the estimated relationship is examined with break-point Chow tests ( $\mathrm{F}$ tests). The results will be robust if parameter constancy is held and accepted by the 1-step break-point Chow Test.

\section{The Empirical Results}

The short run results are quite similar as in the long run. Finance is found to be irrelevant for growth. Our measure of the development of financial intermediaries is the ratio of total credit to the private sector to nominal GDP (PSC). Additionally, we also utilize deposit liabilities of the banking sector as a ratio to nominal GDP as an alternative measure (BDL), where the deposit liabilities are the non-currency components of M2. While the former reflects the extent of financial intermediation, the latter indicates the depth of financial intermediaries as well as the extent of deposit usages. Apart from these variables, we also include other controlled variables in the analysis as to avoid possible omitted variable bias. The following result provides the estimated long-run coefficient using ARDL $(2,0,1,2)$ selected based on the Akaike Information Criterion AIC:

Table1. The Estimated Results

\begin{tabular}{|c|c|c|c|c|}
\hline Variable & Coefficient & Std. Error & t-Statistic & Prob. \\
\hline LSI $_{t}$ & -41.5239 & 23.99441 & -1.73057 & 0.1028 \\
\hline $\operatorname{LINF}_{t}$ & 42.1127 & 23.92026 & 1.760546 & 0.0974 \\
\hline LFD1 & 41.38897 & 23.775 & 1.740861 & 0.1009 \\
\hline LFD2 & -42.5959 & 23.71232 & -1.79636 & 0.0913 \\
\hline R-squared & 0.773832 & $\begin{array}{l}\text { Mean dependent } \\
\text { variable }\end{array}$ & & 3.450185 \\
\hline Adjusted R-squared & 0.731425 & S.D. dependent variable & & 0.965751 \\
\hline S.E. of regression & 0.500493 & Akaike info criterion & & 1.630411 \\
\hline Sum squared residual & 4.007894 & Schwarz criterion & & 1.829557 \\
\hline Log likelihood & -12.3041 & Durbin-Watson stat & & 1.038832 \\
\hline
\end{tabular}

The result clearly shows that financial development is irrelevant for economic growth in Indonesia. The results also indicate the possibility of multicolinearity in the data set. In our study the results of Chow Breakpoint Test shows that F value is higher in 1997, that is, structural break is identified in the year 1997 in Indonesia with the estimated finance-growth relationship. Some interesting observations can be revealed by examining the occurring time of the permanent structural break. In China, the break years were associated with episodic events, such as the Cultural Revolution and the adoption of the market reform and opening to the outside policy, which is in basic accordance with the results found by several scholars whereas in Malaysia, Philippine, Sri Lanka, South Africa and Korea the break years were mainly associated with oil-price shock and domestic economic and financial deregulations (Liang and Teng, 2005). In Indonesia the break year was mainly associated with the 1997 Asian Financial Crisis. The Asian Financial 
Crisis that began to affect Indonesia in mid-1997 became severe economic crisis. Now, one decade later, Indonesia has moved out of crisis and into a situation in which the country once again has sufficient financial resources to address its development needs.

\section{Table2. Chow Breakpoint Test Results}

\begin{tabular}{lcll}
\hline Chow Breakpoint Test: 1995 & & & \\
\hline F-statistic & 2.004795 & Probability & 0.157881 \\
Log likelihood ratio & 10.23568 & Probability & 0.036639 \\
Chow Breakpoint Test: 1996 & & & \\
F-statistic & 4.112738 & Probability & 0.025162 \\
Log likelihood ratio & 17.2655 & Probability & 0.001716
\end{tabular}

Chow Breakpoint Test: 1997

\begin{tabular}{lccc} 
F-statistic & 67.56225 & Probability & 0 \\
Log likelihood ratio & 63.15766 & Probability & 0 \\
Chow Breakpoint Test: 1998 & & & \\
& & & \\
F-statistic & 3.114458 & Probability & 0.056584 \\
Log likelihood ratio & 14.24088 & Probability & 0.006565 \\
\hline
\end{tabular}

\section{Conclusion}

This paper empirically examines the finance-growth nexus for an annual data set of Indonesia during the last two decades. Financial market reform is high on many countries' agenda and is frequently addressed in policy prescription packages by the IMF and the World Bank. It is important to know how financial development policies will affect growth. In fact, one of the reasons why financial sector development is interesting as a determinant of growth is that there is much a government can do to foster or restrain it. Hence the purpose of this study is to examine the causal relationship between financial development and economic growth in Indonesia and to test the structural breaks in the finance-growth relationship due to the change in policy regimes. To examine the causal relationship between financial development and economic growth, the ARDL bound testing approach by Pesaran et al. (1996) has been applied. The evidence presented in this paper provides very little support to the view that finance is a leading sector in the process of economic development. The estimated results support the view of Lucas (1988) that finance doesn't matter for economic growth. Structural break is identified in the year 1997 in Indonesia with the estimated finance-growth relationship. The stability of the estimated relationship is examined with break-point Chow tests ( $\mathrm{F}$ tests). Although Indonesia has made tremendous progress in freeing up financial resources for its development but it really has a very little impact on economic growth. The result is that financial development can not be considered as the policy variable to accelerate economic growth in an economy like Indonesia. This finding has important implications for policy-makers to formulate long-term economic growth and financial development strategy and short-run economic and financial stabilization policies, as well as for academics to carry out cointegration analysis among macroeconomic and financial time series. There are a number of developing countries like Indonesia in which the low region can be identified where a robust positive effect of finance on growth cannot be established. In light of our results, an important policy question is how a country moves to the middle region where the payoff from financial development appears more certain. The threshold to reach a middle region seems fairly low (e.g., about 0.14 for Private Credit; 0.21 for Liquid Liabilities) suggesting that the effect of finance on growth does kick in fairly early. Nevertheless, papers that study poverty traps (e.g., Saint-Paul and Verdier, 1992) show that sustained improvements in financial development can be difficult to engineer especially starting from very low levels. However, it is not clear what the effect is in countries in the low region. Increasing some measures of financial development in these countries may have negligible effects on economic growth. In this sense, the results suggest caution in forecasting the economic growth effects of financial sector expansion. 


\section{References}

Antonios, A. (2010): Financial Development and Economic Growth a Comparative Study between 15 European Member-States, International Research Journal of Finance and Economics, 35(2): 45-62.

Bagehot, W. (1873). Lombard Street. Homewood, 1(1): Richard D. Irwin, [1873] 1962 Edition.

Beck, T., Levine, R. and Loayza, N. (2000). Finance and the sources of growth. Journal of Financial Economics 5(8), 261-300.

Calderon, C. and Liu, L. (2003): The direction of causality between financial development and economic growth, Journal of Development Economics, 72(1), 321- 334.

Chang, T. (2001): Energy consumption, employment, output, and temporal causality: evidence from Taiwan based on cointegration and error-correction modelling techniques, Applied Economics, 3(1): 45-86.

Chia-Hsian, H. (2002): Financial Development and Economic Growth: Evidence from Taiwan. Graduate Research Paper, Department of Economics, Columbian College of Arts and Scie4nces, The George Washington University.

Christopoulos, D. K. and Tsionas, E. G. (2004). Financial development and economic growth: evidence from panel unit root and cointegration tests. Journal of development Economics, 73(4), 55- 74.

Jacques L. E. (2010).Re-examining the finance-growth nexus: structural break, threshold cointegration, and causality evidence from the ECOWAS, Journal of economic development, 35 (3): 1-23.

Gilles, S. P. (1992): Technological Choice, Financial Markets, and Economic, Development, European Economic Review, 36(4): 763-781.

Hansen, B. E. (1992): Tests for Parameter Instability in Regressions with I (1) Processes, Journal of Business and Economic Statistics, 10: 321-335.

Hansen, B. E., and Seo, B. (2002): Testing for Two-Regime Threshold Cointegration in Vector Error-Correction Models, Journal of Econometrics, 110: 293-318.

Hicks, J. (1969). A Theory of Economic History. Oxford: Clarendon Press.

Kemal, A. R., Qayyum, A. and Muhammad, H. N. (2007): Financial Development and Economic Growth: Evidence from a Heterogeneous Panel of High Income Countries, The Lahore Journal of Economics, 12(1): 1-34.

Ketteni, E. (2007): Is the Financial Development and Economic Growth Relationship Nonlinear? Economics Bulletin, 15(14): 1-12.

Levine, R. (1997): Financial Development and Economic Growth: Views and Agenda, Journal of Economic Literature, 35(20):688-726.

Liang, Q and Teng Z. (2006): Financial Development and Economic Growth: Evidence from China, China Economic Review, 17 (2): 395-411.

Liang, $\mathrm{Q}$ and Teng Z. (2007): Reassessment of the finance-growth nexus in the presence of structural breaks, Applied Economics, 15(2): 101-112.

Lucas, R. E. (1988): On the mechanics of economic development, Journal of Monetary Economics, 22: 3-42.

McKinnon, R. I. (1973). Money and Capital in Economic Development. Washington: The Brookings Institution.

Odhiambo, N. M. (2008): Finance-growth-poverty nexus in South Africa: A dynamic causality linkage, The Journal of Socio-Economics, 38(2): 320-325.

Pesaran, S. and Smith, R.J. (1999): Bounds Testing Approaches to the Analysis of Level Relationships, Journal of Applied Econometrics, 16(1): 289-326.

Rioja, F. and Valev, N. (2004): Finance and the Sources of Growth at Various Stages of Economic Development. Economic Inquiry, 42(1): 127-140.

Robinson, J. (1952): The generalization of the general theory, In the Rate of Interest and Other Essays, London: Macmillan, 69-142.

Saint-Paul, G. and Verdier, T. (1992) "Education, Democracy and Growth", Centre for Economic Performance Research, Discussion Paper no 613.

Schumpeter, J. A. (1911). The Theory of Economic Development. Cambridge, Mass: Harvard University Press.

Shaw, E. S. (1973). Financial Deepening in Economic Development. New York: Oxford University Press.

Shen, C. H. and Lee, C. C. (2006). Same Financial Development yet Different Economic Growth-Why? Journal of Money, Credit, and Banking, 38(7): 1907-1944.

Stengos, T. and Liang, Z. (2005). Financial Intermediation and Economic Growth: A Semi parametric Approach. New Trends in Macroeconomics, Springer Berlin Heidelberg, 10.1007/3-540-28556-3, 39-52.

Toda, H. Y., and Yamamoto, T. (1995): Statistical Inference in Vector Auto Regression with Possibly Integrated Processes, Journal of Econometrics, 66(2): 225-250.

Yucel, F. (2009): Causal Relationships between Financial Development, Trade Openness, and Economic Growth: The Case of Turkey, Journal of Social Sciences, 5 (1): 33-42. 